\title{
Inovasi Percepatan Perizinan Pembangunan Perumahan Masyarakat Berpenghasilan Rendah (MBR) Di Daerah
}

\author{
Zanariah \\ Sekretaris Direktur Jenderal Bina Pembangunan Daerah, \\ Kementerian Dalam Negeri \\ admin.perkim@gmail.com
}

\begin{abstract}
ABSTRACK
Part of the main matter of people's welfare is the fulfillment of housing needs Housing development is one of the important things in the regional development strategy, which involves broad aspects in the field of population, and is closely related to economic development and social life in the framework of strengthening national security. Considering the provision of housing is a basic right of the community, the government becomes the leader and prioritizes the priority of fulfilling its needs for the community, especially citizens with low income.

The increase in house prices which is higher than the average inflation rate in Indonesia is one of the causes of the high housing backlog. This condition severely shock low income society or young families whose family economic growth was below the inflation rate. The Regional Government has a big role in the success of the policy, especially so that a million home national programs can reach the target by the end of the Medium-Term Development Plan 2019.

The Economic Policy Package XIII (Paket Kebijakan Ekonomi XIII) that was issued by the Government some time ago regarding Housing for Low Income Society (MBR) is in line with the National Program for the Development of 1 (One) Million Houses. Through the Economic Policy Package, the government bring out a Government Regulation that simplified the number and timing of permits by removing or reducing various permits and recommendations for building MBR houses from as many as 33 permits and stages, to 11 permits and recommendations. With the reduction of the stages, the time for the construction of the MBR that has averaged 769-981 days can be accelerated to 44 days.
\end{abstract}

\section{Kata Kunci : Inovasi, Percepatan Perizinan, Pembangunan Perumahan Bagi Masyarakat Berpenghasilan Rendah}

\section{Pendahuluan}

\section{a. Latar Belakang Masalah}

Perubahan sistem pemerintahan dengan konsep desentralisasi dalam sistem pemerintahan daerah dipertegas dengan tiga peraturan perundangundangan pemerintahan daerah dalam rentang waktu 15 tahun belakang ini. Ketiga undang-undang tentang pemerintahan daerah tersebut yakni UndangUndang Nomor 22 Tahun 1999 yang disempurnakan menjadi Undang-Undang Nomor 32 Tahun 2004 dan yang terbaru adalah Undang-Undang Nomor 23 Tahun 2014 tentang Pemerintahan Daerah. Hal tersebut sekaligus 
22 | Zanariah. Inovasi Percepatan...

menandakan sistem pemerintahan daerah di Indonesia memasuki babak baru, yakni pergeseran dari corak penyelenggaraan pemerintahan daerah yang sentralistik mengarah ke sistem pemerintahan daerah yang desentralistik.

Desentralisasi secara konseptual memiliki banyak sisi positif, seperti Smith (1985:18) meyakini desentralisasi dapat membawa manfaat antara lain: (1) secara ekonomis dianggap mampu meningkatkan efisiensi, karena desentralisasi dapat mengurangi biaya, meningkatkan output, dan human resources dapat dimanfaatkan secara lebih efektif; (2) secara politis, desentralisasi dapat memperkuat demokrasi dan akuntabilitas, meningkatkan kecakapan warga dalam berpolitik, dan memperkuat integrasi nasional.

Kondisi ideal dari sistem pemerintahan daerah Indonesia, baik yang telah ditegaskan dalam Undang-Undang Nomor 32 Tahun 2004 maupun penjelaskan ideal secara teori dan konseptual tentang kebijakan desentralisasi, muaranya tentu saja adalah untuk meningkatkan kesejahteraan masyarakat pada tingkat lokal. Namun demikian setelah lebih satu dekade otonomi daerah rupanya secara empirikal masih bertolak belakang dengan tujuan utamanya. Secara empirikal, pelembagaan inovasi pemerintahan daerah saat ini dapat ditemukan dalam beberapa literatur. Pada tahun 2009, USAID melaporkan adanya beberapa program inovasi manajemen pelayanan publik dilakukan oleh beberapa pemerintahan di tingkat lokal.

Di beberapa daerah otonom lain pun, praktek inovasi penyelenggaraan birokrasi pemerintahan banyak dikembangkan. Daerah otonom yang sukses seringkali menjadi rujukan bagi beberapa daerah otonom lainnya, sebagai best practices penerapan inovasi pemerintahan. kapasitas pemerintah daerah dalam melakukan inovasi di daerahnya tampak berkorelasi positif dengan dukungan masyarakat terhadap pemerintah daerah masing-masing. Adapun bentuk dukungan masyarakat yang paling nyata adalah terpilihnya kembali pemimpin sebelumnya untuk periode kedua.

Pengembangan inovasi pemerintahan daerah di banyak tempat sudah menunjukkan bukti keberhasilan yang secara umum berdampak terhadap perbaikan kinerja pelayanan publik. Meskipun demikian pengembangan inovasi pemerintahan daerah, tetap memiliki beberapa permasalahan dalam pengembangannya. 
Beberapa permasalahan yang dihadapi dalam pengembangan inovasi pemerintahan daerah, antara lain, bahwa permasalahan pengembangan inovasi pemerintahan daerah dapat dilihat dalam perspektif reinventing local government. Dalam perspektif tersebut, permasalahan pengembangan inovasi pemerintahan daerah terajut dalam delapan agenda yang perlu mendapat perhatian serius yang meliputi: pertama, persoalan leadership. Kepemimpinan harus menjadi pendorong perubahan. Pemimpin yang memiliki visi jelas akan mendorong pengikutnya untuk mewujudkan visi tersebut melalui daya kreatif dan daya inovasi yang dimilikinya. Pemimpin yang punya visi tentu tidaklah cukup tetapi dibutuhkan pula kemauan politik, karena kepemimpinan disektor publik bernuansa politik. Tampa kemauan politik yang kuat dari pimpinan pemerintahan daerah hampir mustahil suatu inovasi akan berhasil. (Muhammad, 2007:396)

Pengembangan inovasi pemerintahan daerah berhadapan pula dengan persoalan legalitas yang masih berlangsung saat ini. Persoalan legalitas yang dimaksud adalah persoalan perlindungan hukum terhadap inovasi yang dilakukan oleh aparatur daerah. Secara nasional, Indonesia belum memiliki peraturan perundang-undangan yang mengatur mengenai kewenangan pejabat publik mengambil diskresi dalam pengembangan kebijakan dan program inovatif. Ruang yang tersedia untuk mengambil diskresi bagi aparatur daerah belum diatur dengan jelas sementara tuntutan dan tekanan untuk mengambil tindakan dalam menyelesaikan masalah publik di daerah menuntut aparatur daerah untuk segera bertindak agar masalah dapat diselesaikan dengan baik.

\section{b. Pertanyaan Penelitian}

Tingkat pendapatan masyarakat berpenghasilan rendah juga sangat membatasi kemampuan mereka untuk memenuhi kebutuhan akan perumahan. Berbeda halnya jika terjadi peningkatan penghasilan yang signifikan sehingga dapat memberikan penyelesaian pada kebutuhan akan perumahan. Latar belakang sosial dan budaya juga memberikan pengaruh terhadap kebutuhan akan perumahan. Latar belakang ini akan mempengaruhi keputusan yang diambil dalam rangka pemenuhan kebutuhan perumahan.

Akan tetapi kenyataan dilapangan menunjukkan sesuatu yang berbeda. Tidak setiap keluarga yang bertambah jumlah anggota keluarganya 
24 | Zanariah. Inovasi Percepatan...

serta meningkat perekonomiannya akan mencari rumah baru yang lebih besar. Tidak semua yang kurang mampu akan tetap tinggal. Mengapa begitu banyak macam dan ragam tindakan masyarakat dalam memenuhi kebutuhan perumahannya.

Dengan memperhatikan kondisi permasalahan di atas, maka dalam penelitian ini timbul suatu pertanyaan penelitian yang ingin dikaji yaitu : Bagaimana penyelenggaraan urusan pemerintahan bidang perumahan rakyat dan Kawasan permukiman dilakukan pemerintah dalam melakukan inovasi penyediaan perumahan bagi masyarakat berpenghasilan rendah?

\section{Kajian Teoritis}

\section{a. Konsep Inovasi Organisasi Sektor Publik}

Konsep inovasi dalam sektor publik rupanya belum sepopuler di sektor bisnis. Padahal kajian inovasi dikembangkan seiring dengan upaya menjaga dan bahkan mengembangkan kemampuan berkompetisi (bersaing) atau competitive advantage sebuah organisasi. Kemampuan ini dianggap penting untuk menjaga kelangsungan hidup organisasi. Dalam situasi organisasi yang hidup dengan mengandalkan semata comparative advantage dan pada saat yang sama situasi kompetisi kurang tampak maka konsep inovasi kurang berkembang dengan baik. Hal yang sama juga terjadi pada organisasi publik yang tidak mengkhawatirkan sama sekali masalah kelangsungan hidupnya. (Muluk, $2008: 37$ )

Dalam tulisan Hartley menggambarkan bagaimana hubungan antara kegiatan inovasi (innovation) dan upaya perbaikan (improvement) dalam proses pelayanan publik. Hubungan inovasi dan upaya perbaikan ini menurut Hartley (2005:29) dapat dipahami melalui pendekatan konsep governance dan public management yang dikenal sebagai salah satu paradigma dalam perkembangan pemikiran administrasi publik.

Walaupun konsep inovasi belum lama populer dikalangan ilmuwan maupun dalam prakteknya di organisasi sektor publik, namun dapat dilacak posisi dan relevansi konsep inovasi, baik sebagai nilai maupun sebagai strategi dalam evolusi pemikiran adminisrasi publik. Salah satu sumber dari artikel yang ditulis bersama oleh Vigoda-Gadot, et al (2005:57) berjudul Public Sector Innovation for the Managerial and Post-Managerial Era: Promises and Realities in a Globalizing Public Administration. Artikel ini 
mengulas dan menganalisis bagaimana keterkaitan inovasi (innovation) dengan evolusi pemikiran administrasi publik. Dalam artikel tersebut, VigodaGadot menganalisis kerterkaitan inovasi dan pemikiran administrasi publik. Ada sepuluh pertanyaan diajukan yang mencerminkan posisi konsep inovasi dalam perkembangan pemikiran administrasi publik.

Konsep dasar dalam memahami lebih jauh bagaimana pentingnya kapasitas dimiliki oleh pemerintah daerah dalam melakukan inovasi pada umumnya dapat ditelusuri melalui teori pengembangan kapasitas (theory of capacity building) yang dikembangkan oleh M.S. Grindle (1997:9). Pada tahun 1997, dalam karyanya berjudul Getting Good Government: Capacity Building in the Public Sector of Developing Countries. Dalam buku ini ditegaskan bahwa kapasitas itu menyangkut tiga dimensi yakni (1) dimensi sumberdaya manusia (human resource); (2) dimensi organisasi (organizational strengthening); dan (3) dimensi reformasi kelembagaan (institutional reform). Pada setiap dimensi kapasitas tersebut memiliki fokus penekanan tertentu dan jenis-jenis usaha yang harus dilakukan untuk mengembangkan setiap fokus pada masing-masing dimensi kapasitas. Pada tabel berikut ini memberikan gambaran lebih rinci dari masing-masing dimensi, fokus dan jenis usaha yang mendukungnya.

Tabel 1 : Dimensions and Focus of Capacity-Building Initiatives

\begin{tabular}{|l|l|l|}
\hline \multicolumn{1}{|c|}{ Dimension } & \multicolumn{1}{|c|}{ Focus } & \multicolumn{1}{|c|}{ Types of Activities } \\
\hline $\begin{array}{l}\text { Human resource } \\
\text { development }\end{array}$ & $\begin{array}{l}\text { Supply of professional } \\
\text { and technical personnel }\end{array}$ & $\begin{array}{l}\text { Training, salaries, conditions of } \\
\text { work, recruitment }\end{array}$ \\
\hline $\begin{array}{l}\text { Organizational } \\
\text { strengthening }\end{array}$ & $\begin{array}{l}\text { Management systems to } \\
\text { improve performance of } \\
\text { specific tasks and } \\
\text { functions; } \\
\text { microstructures }\end{array}$ & $\begin{array}{l}\text { Incentive systems, utilization } \\
\text { of personnel, leadership, } \\
\text { organizational culture, } \\
\text { communications, managerial } \\
\text { structures for }\end{array}$ \\
\hline $\begin{array}{l}\text { Institutional } \\
\text { reform }\end{array}$ & $\begin{array}{l}\text { Institutions and system; of the game for } \\
\text { macrostructures }\end{array}$ & $\begin{array}{l}\text { economic and political regime, } \\
\text { policy and legal change, } \\
\text { constitutional reform }\end{array}$ \\
\hline
\end{tabular}

Sumber: Grindle (1997: 9)

Berdasarkan tabel di atas dapat dipahami bahwa dimensi sumberdaya manusia fokus pada tersedianya aparatur yang profesional dan memiliki 
26 | Zanariah. Inovasi Percepatan...

kemampuan teknis. Agar selalu tersedia aparatur yang profesioanl dan memiliki teknis yang diinginkan, maka beberapa kegiatan yang harus dilakukan antara lain: training, pemberian gaji/upah, lingkungan kerja yang kondunsif dan sistim rekruitmen yang tepat. Pada dimensi penguatan organisasi, fokusnya ditujukan pada sistim manajemen untuk memperbaiki kinerja dari fungsi-fungsi dan tugas tugas yang ada dan pengaturan struktur mikro. Aktivitas yang harus dilakukan adalah menata sistim insentif, pemanfaatan personel yang ada, kepemimpinan, komunikasi, dan struktur manajerial.

\section{b. Inovasi Pelayanan Publik}

Inovasi pelayanan publik dikatakan sebagai inisiatif terobosan dari instansi/lembaga publik dalam upaya meningkatkan kualitas pelayanan publik. Inisiatif terobosan tersebut terletak pada kebaruan (novelty). Prinsip kebaruan tersebut dibedakan dengan inovasi dalam teknologi yang merupakan keunikan yang khas berbeda dengan yang lain. Kebaruan boleh merupakan pengembangan dari inovasi pelayanan publik yang telah ada, karena inovasi pelayanan publik terus diperbaharui dan bahkan ditiru dengan cara melakukan replikasi.

Pemikiran inovasi pelayanan publik tidak lepas dari masih lambatnya peningkatan kualitas publik sebagai wujud dari reformasi birokrasi, sementara itu proses reformasi birokrasi yang sekarang sedang berlangsung dilakukan oleh Pemerintah yang mencita-citakan Pemerintahan Kelas Dunia (World Class Government) diharapkan tercapai di Tahun 2025. Inovasi pelayanan publik idealnya harus tumbuh dari budaya organisasi, karena diharapkan akan berkembang dan berkelanjutan mendorong percepatan peningkatan kualitas pelayanan publik. Untuk pertama kali, Kementerian PANRB menegaskan agar inovasi pelayanan publik tersebut terus bergulir menuju tumbuh sebagai budaya organisasi melalui penerapan kebijakan One Agency, One Innovation, yaitu setiap Kementerian/Lembaga dan Pemerintah Daerah wajib untuk menciptakan minimal 1 (satu) Inovasi Pelayanan Publik setiap tahun yang sejalan dengan kewajiban memunculkan Quick Wins sebagai persyaratan pelaksanaan reformasi birokrasi di lingkungan Kementerian/Lembaga dan Pemerintah Daerah. 
Untuk itulah pemerintah daerah harus mampu membangun hubungan yang selaras dan harmonis dengan masyarakat dan dunia usaha untuk mewujudkan tata pemerintahan yang baik (good governance). Agar hubungan yang dimaksud dapat selaras dan harmonis, pemerintah perlu melakukan reposisi sebagai motivator, dinamisator dan inisiator, sehingga kewenangan yang dimiliki mampu menghantarkan masyarakat pada kehidupan yang layak, makmur dan sejahtera.

Pelaksanaan otonomi daerah secara universal mendorong pemerintah Kabupaten/Kota untuk melakukan langkah-langkah kreatif mewujudkan visi dan misi kepala daerah. Adanya kewenangan dalam mengelola sendiri daerahnya, maka pemerintah daerah menganggap paling mengetahui apa saja yang dibutuhkan oleh masyarakatnya. Kemampuan kepala daerah dalam memimpin daerahnya akan nampak pada pencapaian Visi dan Misi yang dibangunsecara konsisten sehingga masyarakat dapat merasakan manfaatnya. Karena visi dan misi merupakan ladasan dalam menyusun arah dan kebijakan. Hanya pada kenyataannya bahwa Visi dan Misi yang dibangun pemerintah daerah seringkali tidak sesuai dengan kebutuhan, karena Visi dan Misi tersebut lebih pada kebutuhan untuk mendapat dukungan masyarakat saat kampanye Pemilihan Kepala Daerah. Walaupun ada juga beberapa daerah yang secara konsisten melaksanakan misi pembangunan untuk memenuhi kebutuhan masyarakatnya.

Masing-masing daerah memiliki keunggulan atas dasar kondisi yang spesifik, kemampuan dan kepentingan pemerintahnya. Bila keunggulan yang ada diberdayakan secara optimal tentu akan dapat memajukan ekonomi daerah yang ditandai dengan kesejahteraan masyarakatnya. Namun, bila keunggulan yang dimaksud hanya untuk sekedar memenuhi asas formal, maka masyarakat tidak akan memperoleh manfaat apa-apa.

\section{Metode Penelitian}

Penelitian ini adalah merupakan jenis penelitian deskriptif yang dilakukan untuk mengetahui nilai variabel, baik satu variabel atau lebih tanpa membuat perbandingan atau menghubungkan antara variabel satu dengan variabel yang lain, dilakukan dengan menggunakan metode penelitian dengan pendekatan kualitatif terhadap data primer maupun data sekunder (Sugiyono, 
28 | Zanariah. Inovasi Percepatan...

2006:11). Dengan pendekatan kualitatif, penelitian ini diharapkan mampu menggali data secara lebih mendalam dan mendapatkan kondisi yang ada secara faktual pada dinas yang dijadikan lokus penelitian, sehingga tujuan penelitian dapat tercapai.

Pengumpulan data dalam penelitian ini dilakukan dengan carawawancara dan mengumpulkan data sekunder dari SKPD terkait berupa Laporan Penerapan dan Pencapaian Standar Pelayanan Minimal dinas, Renstra, Renja, laporan tahunan, Lakip, dan studi kepustakaan (library research) dalam rangka memperkaya penelitian berupa buku, jurnal, hasil penelitian serta informasi-informasi lainnya yang menunjang penelitian ini.

\section{Pembahasan}

\section{a. Kebijakan Pembangunan Perumahan}

Masalah perumahan adalah masalah yang kompleks, yang bukan semata-mata aspek fisik membangun rumah, tetapi terkait sektor yang amat luas dalam pengadaannya, seperti pertanahan, industri bahan bangunan, lingkungan hidup dan aspek sosial ekonomi budaya masyarakat, dalam upaya membangun aspek-aspek kehidupan masyarakat yang harmonis. Oleh karena itu, pembangunan perumahan secara keseluruhan tidak dapat dilepaskan dari keseluruhan pembangunan permukiman dan bagian penting dalam membangun kehidupan masyarakat yang effisien dan produktif. Pembangunan perumahan dan permukiman merupakan kegiatan yang bersifat multi sektor, Hasilnya langsung menyentuh salah satu kebutuhan dasar masyarakat, juga pendorong terjadinya pertumbuhan ekonomi.

Pembangunan di bidang perumahan dan permukiman yang bertumpu pada masyarakat memberikan hak dan kesempatan seluas-luasnya bagi masyarakat untuk berperan serta. Sejalan dengan peran serta masyarakat di dalam pembangunan perumahan dan permukiman pemerintah mempunyai kewajiban dan tanggungjawab untuk melakukan pembinaan dalam wujud pengaturan dan pembimbingan, pendidikan dan pelatihan, pemberian bantuan 
dan kemudahan, penelitian dan pengembangan yang meliputi berbagai aspek yang terkait antara lain tata ruang, pertanahan, prasarana lingkungan, industri bahan dan komponen, jasa konstruksi dan rancang bangun, pembiayaan, kelembagaan, sumber daya manusia, serta peraturan perundang-undangan yang mendukung. Penyelenggaraan rumah dan perumahan dilakukan untuk memenuhi kebutuhan rumah sebagai salah satu kebutuhan dasar manusia bagi peningkatan dan pemerataan kesejahteraan rakyat.

\section{b. Inovasi Percepatan Perizinan Pembangunan Perumahan Bagi Masyarakat Berpenghasilan Rendah}

Inovasi dalam pelayanan sektor publik tidak semata-mata diorientasikan pada faktor teknologi informasi. Memangkas rentang kendali birokrasi juga dapat dikategorikan sebagai inovasi. Selama ini proses perizinan pembangunan perumahan bagi masyarakat berpenghasilan rendah (MBR) relatif panjang dan berbelit-belit khususnya di daerah, sementara perumahan adalah kebutuhan masyarakat yang wajib dipenuhi oleh pemerintah.

Paket Kebijakan Ekonomi (PKE) XIII yang telah dikeluarkan oleh Pemerintah beberapa waktu yang lalu tentang Perumahan untuk Masyarakat Berpenghasilan Rendah (MBR) sejalan dengan Program Nasional Pembangunan 1 (Satu) Juta Rumah sebagai wujud pelaksanaan butir kedua Nawacita, yakni Pemerintah tidak absen untuk membangun pemerintahan yang efektif, demokratis dan terpercaya; dan juga butir kelima, meningkatkan kualitas hidup manusia Indonesia.

Peraturan Pemerintah Nomor 64 Tahun 2016 merupakan peraturan pelaksana atas Undang-Undang Nomor 1 Tahun 2011 tentang Perumahan dan Kawasan Pemukiman dan Paket Kebijakan Ekonomi XIII tentang Perumahan untuk Masyarakat Berpenghasilan Rendah (MBR). Hal ini sejalan dengan Program Nasional Pembangunan satu juta rumah sebagai wujud dari butir kedua yang tertuang dalam amanah Nawacita, yakni Pemerintah tidak absen untuk membangun pemerintahan yang efektif, demokratis dan terpercaya; dan juga butir kelima, meningkatkan kualitas hidup manusia Indonesia. 
30 | Zanariah. Inovasi Percepatan...

Dalam mendorong hal diatas, Kementerian Dalam Negeri (Kemendagri) menerbitkan Peraturan Mendagri Nomor 55 Tahun 2017 tentang Pelaksanaan Perizinan dan Non Perizinan Pembangunan Perumahan Bagi Masyarakat Berpenghasilan Rendah (MBR) di Daerah. Aturan tersebut diterbitkan guna mendorong percepatan pembangunan perumahan bagi MBR di daerah melalui Program Sejuta Rumah. Peraturan ini akan mendorong pemerintah daerah memerankan fungsinya dengan kemudahan pelayanan. Hal tersebut dilakukan melalui penghapusan izin, penggabungan beberapa izin, atau kemudahan pemberian waktu perizinan. Sebelumnya juga Menteri Dalam Negeri (Mendagri) mengeluarkan Surat Edaran Menteri Dalam Negeri Nomor 668/1062/SJ Tentang Percepatan Pembangunan Perumahan Masyarakat Berpenghasilan Rendah (MBR) di daerah. Surat edaran yang dikeluarkan 27 Februari 2017 ini menindaklanjuti Paket Kebijakan Ekonomi XIII tentang penyederhanaan perizinan dan Peraturan Pemerintah (PP) tentang Pembangunan Perumahan MBR.

Melalui Paket Kebijakan Ekonomi XIII, pemerintah menerbitkan Peraturan Pemerintah yang menyederhanakan jumlah dan waktu perizinan dengan menghapus atau mengurangi berbagai izin dan rekomendasi untuk membangun rumah MBR dari semula sebanyak 33 izin dan tahapan, menjadi 11 izin dan rekomendasi. Dengan pengurangan tahapan itu, maka waktu pembangunan MBR yang selama ini rata-rata mencapai 769-981 hari dapat dipercepat menjadi 44 hari. Adapun rinciannya:

a. Perizinan yang dihilangkan antara lain: izin lokasi dengan waktu 60 hari kerja, persetujuan gambar master plan dengan waktu 7 hari kerja, rekomendasi peil banjir dengan waktu 30-60 hari kerja, persetujuan dan pengesahan gambar site plan dengan waktu 5-7 hari kerja dan Analisa Dampak Lingkungan Lalu Lintas (Andal Lalin) dengan waktu 30 hari kerja.

b. Perizinan yang digabungkan, meliputi: (1) Proposal Pengembang (dengan dilampirkan Sertifikat tanah, bukti bayar PBB (tahun terakhir) dengan Surat Pernyataan Tidak Sengketa (dilampirkan dengan peta rincikan tanah/blok plan desa) jika tanah belum bersertifikat; (2) Ijin Pemanfaatan Tanah (IPT)/ Ijin Pemanfaatan Ruang (IPR) digabung dengan tahap pengecekan kesesuaian RUTR/RDTR wilayah (KRK) dan Pertimbangan Teknis Penatagunaan Tanah/Advise Planning, 
Pengesahan site plan diproses bersamaan dengan izin lingkungan yang mencakup: SPPL atau Surat Pernyataan Pengelolaan Lingkungan (sampai dengan luas lahan $5 \mathrm{Ha}$ ); serta (3) Pengesahan site plan diproses bersamaan dengan izin lingkungan yang mencakup SPPL (luas < 5 ha), rekomendasi damkar, dan retribusi penyediaan lahan pemakaman atau menyediakan pemakaman.

c. Perizinan yang dipercepat, antara lain: (1) Surat Pelepasan Hak (SPH) Atas Tanah dari Pemilik Tanah kepada pihak developer (dari 15 hari menjadi 3 hari kerja); (2) Pengukuran dan pembuatan peta bidang tanah (dari 90 hari menjadi 14 hari kerja); (3) Penerbitan IMB Induk dan pemecahan IMB (dari 30 hari menjadi 3 hari kerja); (4) Evaluasi dan Penerbitan SK tentang Penetapan Hak Atas Tanah (dari 213 hari kerja menjadi 3 hari kerja); (5) Pemecahan sertifikat a/n pengembang (dari 120 hari menjadi 5 hari kerja); dan (6) Pemecahan PBB atas nama konsumen (dari 30 hari menjadi 3 hari kerja).

\section{Penutup}

Dalam rangka percepatan perizinan pembangunan perumahan bagi masyarakat berpenghasilan rendah (MBR) sesuai dengan amanah Peraturan Pemerintah Nomor 64 Tahun 2016 tentang Pembangunan Perumahan Masyarakat Berpenghasilan Rendah dan Peraturan Menteri Dalam Negeri Nomor 55 Tahun 2017 tentang Pelaksanaan Perizinan dan Non Perizinan Pembangunan Perumahan Bagi Masyarakat Berpenghasilan Rendah di Daerah, maka diperlukan asistensi bagi daerah untuk menyusun Perkada sebagai upaya percepatan instrumen hukum bagi daerah.

Pemerintah Daerah memiliki kewenangan atributif dalam menyusun produk hukum daerah sesuai dengan Peraturan Menteri Dalam Negeri Nomor 80 Tahun 2015 tentang Pembentukan Produk Hukum Daerah, oleh karena itu melalui Kementerian Dalam Negeri dalam rangka pembinaan umum dianggap perlu melakukan asistensi produk hukum daerah terkait percepatan pembangunan perumahan bagi Masyarakat Berpenghasilan Rendah (MBR) sebagai konsistensi implementasi Peraturan Menteri Dalam Negeri Nomor 55 Tahun 2017 tentang Pelaksanaan Perizinan dan Non Perizinan Pembangunan Perumahan Bagi Masyarakat Berpenghasilan Rendah di Daerah. 
32 | Zanariah. Inovasi Percepatan...

Dalam mendorong percepatan perizinan pembangunan perumahan bagi masyarakat berpenghasilan rendah, maka dari peraturan yang sudah ada, maka Kementerian Dalam Negeri dan Kementerian PUPR melakukan terobosan guna percepatan tersebut dengan melakukan asistensi pembentukan regulasi atributif tentang percepatan perizinan pembangunan perumahan bagi masyarakat berpenghasilan rendah dari aspek substansi, teknis dan regulasi agar dapat memenuhi target program sejuta rumah. Serta mengidentifikasi kendala dan hambatan dalam pelaksanaan penerapan kemudahan perizinan perumahan MBR di daerah.

\section{DAFTAR PUSTAKA}

Grindle, Merilee S, (Editor), Getting Good Government: Capacity Building in the Public Sector of Developing Countries. MA: Harvard Institute for International Development. Boston. 1997.

Hartley, Jean, Innovation in Governance and Public Services: Past and Present. Public Money and Management. January, Blackwell Publishing. 2005.

Muhammad, Fadel, Reinventing Local Government: Pengalaman dari Daerah, Gramedia. Jakarta 2009.

Muluk, Khairul, Knowledge Management ; Kunci Sukses Inovasi Pemerintahan Daerah, Bayu Media. Malang. 2008.

Rondinelli, Dennis A \& Cheema, G. Shabbir, Decentralization and Development Policy Implementation in Developing Countries. Sage Publications. Beverly Hills London. 1983.

Sugiyono, Metode Penelitian Administrasi dilengkapi dengan Metode R\&D. Alfabeta, Bandung. 2006.

Smith, Brian C., Decentralization: The Territorial Dimension of the State, George Allen \& Unwin. London. 1985.

Osborne, David \& Ted Gaebler, Reinventing Government: How the Entrepreneurial Spirit Is Transforming the Public Sector, Reading MA : Addison-Wesley. 1992.

Vigoda-Gadot, Eran, Aviv Shoham, Nitza Schwabsky, \& Ayalla Ruvi, Public Sector Innovation for the Managerial and Post-Managerial Era: Promises and Realities in a Globalizing Public Administration. International Public Management Journal. 8 (1). 2005. 
Peraturan Pemerintah Nomor 64 Tahun 2016 tentang Pembangunan Perumahan Masyarakat Berpenghasilan Rendah

Peraturan Mendagri Nomor 55 Tahun 2017 tentang Pelaksanaan Perizinan dan Non Perizinan Pembangunan Perumahan Bagi Masyarakat Berpenghasilan Rendah (MBR) di Daerah 